\title{
Immunoglobulin allotype gene polymorphisms in systemic sclerosis: interactive effect of MHC class II and KM genes on anticentromere antibody production
}

Hideto Kameda, Janardan P Pandey, Junichi Kaburaki, Hidetoshi Inoko, Masataka Kuwana

\begin{abstract}
Objective-To examine potential interactions between immunoglobulin (Ig)allotype gene polymorphisms and susceptibility to systemic sclerosis (SSc) as well as serological expression in SSc patients.
\end{abstract}

Methods-IgG heavy chain allotypes $\operatorname{G1M}(\mathbf{f}, \mathrm{z}), \mathbf{G} 2 M(\mathrm{n}+, \mathbf{n -}), \mathbf{G} 3 M(b, g)$ and $I g$ light chain allotype $\operatorname{KM}(1,(1,2), 3)$ were genotyped in 105 Japanese SSc patients and 47 race matched normal controls using polymerase chain reaction (PCR) based methods. Associations of each Ig allotype with SSc related antinuclear antibodies were examined in combination with or without MHC class II alleles.

Results-GM/KM genotypic and allelic frequencies were similar in SSc patients and in normal controls. Frequencies of $\operatorname{G1M}(\mathbf{f})$ and $\operatorname{G} 2 M(n+)$ were significantly decreased in anticentromere antibody (ACA) positive SSc patients compared with ACA negative SSc patients $(p=0.04$ and 0.02 , respectively). Conversely, the presence of $D Q B 1{ }^{\star} 0501$ and $K M(1,2)$ significantly increased the risk of ACA positivity.

Conclusion-Ig allotype gene polymorphisms were not associated with susceptibility to SSc. Instead, the results suggested that MHC class II and KM genes are associated with autoimmune responses by interactively promoting the production of ACA.

(Ann Rheum Dis 1998;57:366-370)

Systemic sclerosis (SSc) is a disease characterised by fibrosis of the dermis and internal organs, microvascular injury, and the presence of circulating antinuclear antibodies (ANAs) to various nuclear proteins such as DNA topoisomerase I (topo I) and centromere/ kinetochore. ${ }^{1}$ The aetiology of SSc remains unclear, but genetic factors are believed to influence its development, based on epidemiological studies showing familial clustering of SSc and SSc related disorders including Raynaud's phenomenon. ${ }^{2}$ Genes located within the major histocompatibility complex (MHC) locus have been extensively analysed as candidate genes for susceptibility to SSc, but the findings have suggested that MHC class II genes were associated less with SSc in itself but were instead associated with the expression of SSc related ANAs. ${ }^{3}$ We have found MHC class II gene associations with serum SSc related ANAs in Japanese, including anti-topo I antibody with $\mathrm{DRB} 1^{\star} 1502^{4}$ and anticentromere antibody (ACA) with DQB $1{ }^{\star} 0501 .^{5}$ Moreover, anti-U1 small nuclear ribonucleoprotein (U1snRNP) antibodies, primarily detected in SSc patients with overlap features of lupus and/or myositis, were associated with DQB $1^{\star} 0302$ in Japanese patients with connective tissue disease. ${ }^{6}$

The immune response genes, which control immune responses to specific antigens, include MHC genes and genes coding for the immunoglobulin (Ig) allotypic markers, the latter are located in the constant regions of Ig heavy and light chains. ${ }^{7}$ Previous studies have shown associations between Ig allotypic phenotypes and susceptibility to several autoimmune diseases including systemic lupus erythematosus, ${ }^{8}$ myasthenia gravis, ${ }^{9}$ and Graves' disease..$^{10}{ }^{11}$ The presence of specific ANAs in patients with autoimmune diseases was also shown to be associated with Ig allotypes. ${ }^{12} 13$ Interactive effects of MHC antigens and Ig allotypes on the production of antibodies directed against foreign and self antigens have been demonstrated. ${ }^{14}{ }^{15}$ However, influences of Ig allotypes on serological expression in SSc patients are largely undefined.

Recently, gene organisation of the Ig loci has been extensively analysed and polymerase chain reaction (PCR) based molecular typing methods for Ig allotypic markers have been established. ${ }^{16-19}$ In this study, therefore, we identified Ig allotype gene polymorphisms in Japanese patients with SSc and examined for associations of these markers with ANA status in SSc patients. Interactive effects of the two independent immune response genes, MHC class II and Ig allotypes, on SSc related ANA responses were also investigated.

\section{Methods}

PATIENTS AND CONTROLS

We studied 105 unrelated Japanese SSc patients, all of whom satisfied the American College of Rheumatology (ACR; formerly the American Rheumatism Association) preliminary classification criteria of SSc. ${ }^{20}$ Ninety five SSc patients in this study had been analysed in our previous studies that examined for associations between MHC class II alleles and SSc related ANAs. ${ }^{4-6}$ All SSc patients had been
Accepted for publication 18 May 1998 
Table 1 GM/KM allotype gene polymorphisms analysed in this study

\begin{tabular}{|c|c|c|c|c|c|c|c|}
\hline System & Subclass & Domain & Nomenclature & $\begin{array}{l}\text { Chromosomal } \\
\text { location }\end{array}$ & $\begin{array}{l}\text { Typing } \\
\text { method }\end{array}$ & $\begin{array}{l}\text { Polymorphic } \\
\text { position (s) }\end{array}$ & Reference \\
\hline \multirow[t]{3}{*}{ GM } & IgG1 & $\mathrm{CH} 1$ & $\mathrm{G} 1 \mathrm{M}(\mathrm{f}, \mathrm{z})$ & $14 \mathrm{q} 32.33$ & PCR-SSO & codon 214 & 16 \\
\hline & IgG2 & $\mathrm{CH} 2$ & $\mathrm{G} 2 \mathrm{M}(\mathrm{n}+, \mathrm{n}-)$ & $14 \mathrm{q} 32.33$ & PCR-RFLP & codon 282 & 17 \\
\hline & IgG3 & $\begin{array}{l}\mathrm{CH} 2 \\
\mathrm{CH} 3\end{array}$ & $\mathrm{G} 3 \mathrm{M}(\mathrm{b}, \mathrm{g})$ & $14 \mathrm{q} 32.33$ & PCR-RFLP & $\begin{array}{l}\text { codons } 291,296 \\
\text { codon } 384\end{array}$ & 18 \\
\hline $\mathrm{KM}$ & & CL & $\mathrm{KM}(1,(1,2), 3)$ & $2 \mathrm{p} 12$ & PCR-RFLP & codons 153,191 & 19 \\
\hline
\end{tabular}

PCR-SSO = polymerase chain reaction and sequence specific oligonucleotide probes, PCR-RFLP = polymerase chain reaction and restriction fragment length polymorphisms.

observed regularly by clinical staff of the Division of Rheumatology, Keio University Hospital for more than three years or had died of causes related to SSc within three years of diagnosis. The mean time between their first visit and the latest follow up evaluation was 8.9 years (range $0.8-24$ years). Forty seven unrelated healthy Japanese volunteers living in Tokyo metropolitan area were selected as race matched normal controls.

ANA ASSAYS

Serum samples, obtained from SSc patients at first visit, were stored at $-20^{\circ} \mathrm{C}$. Three major SSc related ANAs were identified as described previously; anti-topo I and anti-U1snRNP antibodies by double immunodiffusion using rabbit thymus extract as an antigen source and immunoprecipitation assays using ${ }^{35} \mathrm{~S}$-labelled HeLa cell extracts; and ACA by indirect immunofluorescence on HeLa cell chromosomal spreads. ${ }^{21}$

MHC CLASS II ALLELE GENOTYPING

The DRB1, DQB1, and DPB1 genes were typed using restriction fragment length polymorphisms of PCR amplified genomic DNA as described previously. ${ }^{22}$ The numbers of alleles defined by this method are 52 (DRB1), 17 (DQB1), and 19 (DPB1).

IG ALLOTYPE GENOTYPING

Genotyping of Ig heavy chain (GM) and light chain (KM) allotypes was carried out as

Table 2 Genotypic and allelic frequencies of GM/KM allotypes in SSc patients and normal controls

\begin{tabular}{|c|c|c|c|c|c|}
\hline Ig allotypes & & $\begin{array}{l}S S c \\
(n=105)\end{array}$ & $\begin{array}{c}\text { Normal } \\
\text { controls } \\
(n=47)\end{array}$ & $p$ Value & OR $(95 \% C I)$ \\
\hline \multicolumn{6}{|c|}{ Genotypic frequency (\%) } \\
\hline \multirow[t]{3}{*}{$\mathrm{G} 1 \mathrm{M}$} & $\mathrm{f}$ & 1 & 0 & ns & - \\
\hline & $\mathrm{z}$ & 79 & 89 & ns & $0.44(0.14$ to 1.5$)$ \\
\hline & $\mathrm{f}, \mathrm{z}$ & 21 & 11 & ns & $2.1(0.61$ to 7.2$)$ \\
\hline \multirow[t]{3}{*}{$\mathrm{G} 2 \mathrm{M}$} & $n+$ & 1 & 0 & ns & - \\
\hline & $\mathrm{n}-$ & 78 & 87 & ns & $0.52(0.16$ to 1.7$)$ \\
\hline & $\mathrm{n}+, \mathrm{n}-$ & 21 & 13 & ns & $1.8(0.55$ to 6.0$)$ \\
\hline \multirow[t]{4}{*}{$\mathrm{G} 3 \mathrm{M}$} & $\mathrm{b}$ & 7 & 0 & ns & - \\
\hline & $\mathrm{g}$ & 70 & 77 & ns & $0.73(0.25$ to 2.1$)$ \\
\hline & $\mathrm{b}, \mathrm{g}$ & 15 & 11 & ns & $1.5(0.31$ to 7.5$)$ \\
\hline & untypable & 8 & 13 & ns & $0.56(0.12$ to 2.7$)$ \\
\hline \multirow[t]{3}{*}{$\mathrm{KM}$} & $(1,2)$ & 9 & 9 & ns & $1.0(0.96$ to 1.1$)$ \\
\hline & 3 & 45 & 49 & ns & $0.85(0.29$ to 2.5$)$ \\
\hline & $(1,2), 3$ & 47 & 43 & $\mathrm{~ns}$ & $1.2(0.39$ to 3.6$)$ \\
\hline \multicolumn{6}{|c|}{ Allelic frequency (\%) } \\
\hline \multirow[t]{2}{*}{ G1M } & $\mathrm{f}$ & 21 & 11 & ns & $2.2(0.67$ to 7.4$)$ \\
\hline & $\mathrm{z}$ & 99 & 100 & ns & - \\
\hline \multirow[t]{2}{*}{$\mathrm{G} 2 \mathrm{M}$} & $\mathrm{n}+$ & 22 & 13 & ns & $1.9(0.60$ to 6.1$)$ \\
\hline & $\mathrm{n}-$ & 99 & 100 & ns & $2.3\left(0\right.$ to $\left.10^{5}\right)$ \\
\hline \multirow[t]{2}{*}{$\mathrm{G} 3 \mathrm{M}+$} & $\mathrm{b}$ & 24 & 12 & ns & $2.2(0.67$ to 7.5$)$ \\
\hline & $\mathrm{g}$ & 93 & 100 & $\mathrm{~ns}$ & - \\
\hline \multirow[t]{3}{*}{$\mathrm{KM}$} & 1 & 0 & 0 & ns & - \\
\hline & $(1,2)$ & 55 & 51 & ns & $1.2(0.40$ to 3.5$)$ \\
\hline & 3 & 91 & 91 & ns & $1.0(0.94$ to 1.0$)$ \\
\hline
\end{tabular}

$\mathrm{ns}=$ Not significant $(\mathrm{p}>0.05) .{ }^{\star} \mathrm{G} 3 \mathrm{M}$ could not be typed in a total of 14 subjects. †Eight SSc patients and six normal controls in whom G3M was untypable were excluded. described previously. ${ }^{16-19} \mathrm{GM} / \mathrm{KM}$ allotype polymorphisms analysed in this study are summarised in table 1. Briefly, the G1M, G2M, $\mathrm{G} 3 \mathrm{M}$, and $\mathrm{KM}$ genes corresponding to the $\mathrm{CH}$ domains including known polymorphisms were amplified using subclass specific primers. Nucleic acid differences were discriminated by restriction enzyme digestion of PCR amplified products (PCR-RFLP; G2M, G3M, and KM) or hybridisation of PCR amplified products with sequence specific oligonucleotide probes (PCR-SSO; G1M).

STATISTICAL ANALYSIS

Differences in frequencies were analysed by Fisher's two tailed exact tests. Odds ratio (OR) with $95 \%$ confidence intervals $(95 \% \mathrm{CI})$ were also calculated.

To analyse interactive effects of MHC class II alleles and GM/KM allotypes on SSc related ANA responses, complex interactions for contingency tables were investigated by fitting loglinear models according to the hierarchial principle. ${ }^{1523}$ Interaction between a particular combination of the MHC class II allele and the $\mathrm{GM} / \mathrm{KM}$ allotype on the production of certain SSc related ANA was considered to be present when all of the following findings was satisfied: (a) risk for developing the SSc related ANA response affected by non-additive effects of two genetic markers (MHC class II alleles and GM/KM allotypes) was significant by appropriate $G_{2}$ likelihood ratio statistic; (b) when individuals with neither risk were taken as a reference, frequency of individuals possessing both genetic markers in the ANA positive patients was significantly increased compared with those in the ANA negative patients and normal controls, using pairwise comparisons by Fisher's exact tests; and (c) frequency of individuals possessing a single genetic marker in the ANA positive patients was not significantly increased compared with those in the ANA negative patients and normal controls.

\section{Results}

GM/KM ALLOTYPES IN SSC AND NORMAL CONTROLS

Genotypic and allelic frequencies of $\mathrm{GM} / \mathrm{KM}$ allotypes including $\mathrm{G} 1 \mathrm{M}(\mathrm{f}, \mathrm{z}), \mathrm{G} 2 \mathrm{M}(\mathrm{n}+, \mathrm{n}-)$, $\mathrm{G} 3 \mathrm{M}(\mathrm{b}, \mathrm{g})$, and $\mathrm{KM}(1,(1,2), 3)$ were compared between $105 \mathrm{SSc}$ patients and 47 normal controls (table 2). G3M(b, g) could not be typed in eight SSc patients and in six normal controls because of the failure to obtain PCR amplified products with an appropriate molecular size. $\mathrm{G} 1 \mathrm{M}(\mathrm{z})$ and $\mathrm{G} 2 \mathrm{M}(\mathrm{n}-)$ were detected in nearly all SSc patients and normal controls, whereas $\mathrm{KM}(1)$ was detected in none 
of our subjects. $\mathrm{G} 1 \mathrm{M}(\mathrm{f}), \mathrm{G} 2 \mathrm{M}(\mathrm{n}+)$, and $\mathrm{G} 3 \mathrm{M}(\mathrm{b})$ tended to be frequently detected in SSc patients compared with normal controls, but these differences did not reach statistical significance.

GM/KM ALLOTYPES AND SSC-RELATED ANAS Serum anti-topo I, anti-U1snRNP, ACA were detected in 37 (35\%), $35(33 \%)$, and $23(22 \%)$ of 105 SSc patients, respectively. Seven patients had both anti-topo I and anti-U1snRNP antibodies, but none of ACA positive patients had coexistent anti-topo I or anti-U1snRNP antibody. Frequency of each GM/KM allele was compared according to the presence or absence of these three major SSc related ANAs (table 3 ). We could not find any significant difference in distribution of $\mathrm{GM} / \mathrm{KM}$ alleles between anti-topo I-positive and negative SSc nor between anti-U1snRNP positive and negative SSc. In contrast, G1M(f) was found in only one ACA positive SSc patient (4\%) compared with $21(26 \%)$ ACA negative patients ( $\mathrm{p}=$ $0.04, \mathrm{OR}=0.13)$. Similarly, $\mathrm{G} 2 \mathrm{M}(\mathrm{n}+)$ was significantly less frequently detected in ACA positive SSc patients compared with ACA negative SSc patients $(\mathrm{p}=0.02, \mathrm{OR}=0.12)$. Frequency of $\mathrm{G} 3 \mathrm{M}(\mathrm{b})$, which is in linkage disequilibrium with $\mathrm{G} 1 \mathrm{M}(\mathrm{f})$ and $\mathrm{G} 2 \mathrm{M}(\mathrm{n}+)$ in Japanese, ${ }^{24}{ }^{25}$ was marginally decreased in ACA positive compared with negative SSc patients. As a result, SSc patients with ACA were homogeneous in terms of the GM phenotype, as 21 $(91 \%)$ of 23 ACA positive patients had the G1M(z)/G2M(n-)/G3M(g) phenotype, which was found in $52(63 \%)$ of 82 ACA negative SSc patients $(\mathrm{p}=0.01, \mathrm{OR}=6.1,95 \% \mathrm{CI} 1.5$ to 24.2). These results indicated that $\mathrm{G} 1 \mathrm{M}(\mathrm{f})$ and $\mathrm{G} 2 \mathrm{M}(\mathrm{n}+)$ were negatively associated with ACA in SSc patients. However, frequencies of G1M(f), G2M(n+), and G3M(b) were not different between ACA positive SSc patients compared with normal controls, and G1M(f) and $\mathrm{G} 3 \mathrm{M}(\mathrm{b})$ were significantly more frequently detected in ACA negative SSc patients compared with normal controls $(\mathrm{p}=0.04$, OR $=2.9,95 \%$ CI 1.0 to 8.1 in both comparisons). Therefore, it is also possible that G1M(f) and $\mathrm{G} 3 \mathrm{M}(\mathrm{b})$ were associated with ACA negative SSc.

INTERACTIVE EFFECT OF MHC CLASS II AND GM/KM GENES ON PRODUCTION OF SSC RELATED ANAS The strongest associations between three major SSc related ANAs (anti-topo I, antiU1snRNP, and ACA) and MHC class II alleles found were; DRB1 ${ }^{\star} 1502$ detected in $26(70 \%)$ anti-topo I positive SSc compared with 20 (29\%) anti-topo I negative SSc and $13(28 \%)$ normal controls $(\mathrm{p}=0.0001$ and 0.0002 , respectively); DQB $1{ }^{\star} 0302$ detected in 14 (40\%) anti-U1snRNP positive SSc compared with $14(20 \%)$ anti-U1snRNP negative SSc and five $(11 \%)$ normal controls $(p=0.03$ and 0.003 , respectively); and DQB ${ }^{\star} 0501$ detected in nine $(39 \%)$ ACA positive SSc compared with nine $(11 \%)$ ACA negative SSc and five (13\%) normal controls ( $\mathrm{p}=0.004$ and 0.009 , respectively). We further examined possible interactive effects of MHC class II alleles and Ig allotypes on the production of SSc related ANAs. Table 4 shows frequencies of all combinations of the presence or absence of $\mathrm{DQB} 1^{\star} 0501$ and $\mathrm{KM}(1,2)$ in ACA positive SSc, ACA negative SSc, and normal controls. Analysis by fitting log-linear models showed the presence of three way interactions among $\mathrm{DQB} 1{ }^{\star} 0501, \mathrm{KM}(1,2)$, and $\mathrm{ACA}\left(\mathrm{G}_{2}=21.2\right.$, $p=0.002)$. When individuals with none of the three factors were taken as a reference, relative risk estimated by odds ratios for DQB $1{ }^{\star} 0501 /$ $\operatorname{KM}(1,2)$ carriers to develop ACA response was 8.0 in both comparisons. In contrast, frequencies of individuals having either $\mathrm{DQB} 1{ }^{\star} 0501$ or $\mathrm{KM}(1,2)$ alone were not increased in ACA positive SSc compared with

Table 3 Allele frequency (\%) of GM/KM allotypes in SSc patients according to the presence or absence of SSc related ANAs

\begin{tabular}{|c|c|c|c|c|c|c|c|c|c|c|c|c|c|}
\hline \multirow{2}{*}{\multicolumn{2}{|c|}{ Ig allotypes }} & \multicolumn{4}{|c|}{ Anti-topo I antibody } & \multicolumn{4}{|c|}{ Anti-U1snRNP antibody } & \multicolumn{4}{|l|}{$A C A$} \\
\hline & & $\begin{array}{l}\text { Positive } \\
(n=37)\end{array}$ & $\begin{array}{l}\text { Negative } \\
(n=68)\end{array}$ & $\stackrel{p}{\text { Value }}$ & OR $(95 \% C I)$ & $\begin{array}{c}\text { Positive } \\
(n=35)\end{array}$ & $\begin{array}{l}\text { Negative } \\
(n=70)\end{array}$ & $\stackrel{p}{\text { Value }}$ & OR $(95 \% C I)$ & $\begin{array}{l}\text { Positive } \\
(n=23)\end{array}$ & $\begin{array}{l}\text { Negative } \\
(n=82)\end{array}$ & $\stackrel{p}{\text { Value }}$ & OR $(95 \% C I)$ \\
\hline \multirow[t]{2}{*}{ G1M } & $\mathrm{f}$ & 22 & 21 & ns & $1.1(0$ to 2.8$)$ & 26 & 19 & ns & $1.5(0.38$ to 6.0$)$ & 4 & 26 & 0.04 & $0.13(0.02$ to 0.79$)$ \\
\hline & $\mathrm{z}$ & 100 & 99 & ns & - & 97 & 100 & ns & - & 100 & 99 & $\mathrm{~ns}$ & - \\
\hline \multirow[t]{2}{*}{ G2M } & $\mathrm{n}+$ & 24 & 21 & ns & $1.2(0.14$ to 10.8$)$ & 29 & 19 & ns & $1.8(0.53$ to 5.8$)$ & 4 & 27 & 0.02 & $0.12(0.02$ to 0.73$)$ \\
\hline & $\mathrm{n}-$ & 100 & 99 & ns & - & 97 & 100 & ns & - & 100 & 99 & ns & - \\
\hline \multirow{2}{*}{$\mathrm{G} 3 \mathrm{M}^{\star}$} & $\mathrm{b}$ & 24 & 24 & ns & $1.0(0.86$ to 1.1$)$ & 30 & 21 & ns & $1.6(0.43$ to 6.1$)$ & 9 & 28 & ns & $0.24(0.04$ to 1.3$)$ \\
\hline & $\mathrm{g}$ & 94 & 92 & ns & $1.4\left(0\right.$ to $\left.10^{5}\right)$ & 90 & 94 & ns & $0.57(0.01$ to 27.1$)$ & 100 & 91 & ns & - \\
\hline \multirow[t]{2}{*}{$\mathrm{KM}$} & $(1,2)$ & 57 & 54 & ns & $1.1\left(0\right.$ to $\left.10^{5}\right)$ & 51 & 57 & ns & $0.79(0.22$ to 2.9$)$ & 52 & 56 & ns & 0.85 (0.03 to 22.2$)$ \\
\hline & 3 & 86 & 94 & $\mathrm{~ns}$ & $0.4(0.06$ to 2.5$)$ & 91 & 91 & $\mathrm{~ns}$ & $1.0(1.0$ to 1.0$)$ & 96 & 90 & $\mathrm{~ns}$ & $2.4(0.03$ to 170$)$ \\
\hline
\end{tabular}

$\mathrm{ns}=$ Not significant $(\mathrm{p}>0.05) .{ }^{\star}$ Eight $S S c$ patients in whom G3M was untypable were excluded.

Table 4 Combination of $D Q B 1^{\star} 0501$ and $K M(1,2)$ in ACA positive and negative SSc patients and normal controls

\begin{tabular}{|c|c|c|c|c|c|c|c|c|c|c|c|}
\hline \multirow[b]{2}{*}{$D Q B 1 * 0501$} & \multirow[b]{2}{*}{$K M(1,2)$} & \multicolumn{2}{|c|}{$A C A(+) S S c(n=23)$} & \multicolumn{2}{|c|}{$A C A(-) S S c(n=82)$} & \multicolumn{2}{|c|}{ Normal controls $(n=47)$} & \multicolumn{2}{|l|}{$\begin{array}{l}A C A(+) S S c \text { versus } \\
A C A(-) S S c\end{array}$} & \multicolumn{2}{|c|}{$\begin{array}{l}\text { ACA }(+) S S c \text { versus normal } \\
\text { controls }\end{array}$} \\
\hline & & Observed & Expected ${ }^{\star}$ & Observed & Expected $^{*}$ & Observed & Expected ${ }^{\star}$ & $O R(95 \%) t$ & $\stackrel{p}{\text { Valuet }}$ & OR $(95 \% C I)+$ & $\stackrel{p}{\text { Valuet }}$ \\
\hline+ & + & $8(35 \%)$ & 2.0 & $3(4 \%)$ & 7.0 & $2(4 \%)$ & 4.0 & $8.0(2.0$ to 32.0$)$ & 0.01 & $8.0(1.6$ to 39.1$)$ & 0.02 \\
\hline+ & - & $1(4 \%)$ & 1.5 & $6(7 \%)$ & 5.4 & $3(6 \%)$ & 3.1 & $0.50\left(0\right.$ to $\left.10^{5}\right)$ & 1.0 & $0.67(0.02$ to 19.0$)$ & 1.0 \\
\hline - & + & $4(17 \%)$ & 10.4 & $43(52 \%)$ & 37.2 & $22(47 \%)$ & 21.3 & 0.28 (0.08 to 0.92$)$ & 0.04 & $0.36(0.07$ to 1.8$)$ & 0.2 \\
\hline - & - & $10(43 \%)$ & 9.1 & $30(37 \%)$ & 32.4 & $20(43 \%)$ & 18.6 & 1 & & 1 & \\
\hline
\end{tabular}

Significance of three way interaction (DQB $1^{\star} 0501, \mathrm{KM}(1,2)$, and ACA) was $\mathrm{G}^{2}=21.2, \mathrm{p}=0.002 .{ }^{\star}$ Expected values were calculated assuming independence of the two genetic markers for development of ACA. +Subjects with neither risk factor were taken as a reference. $p$ Values were calculated using pairwise comparisons by Fisher's exact tests. 
ACA negative SSc and in normal controls, indicating that the significance in three way interactions was contributed by the combination of both $\mathrm{DQB} 1{ }^{\star} 0501$ and $\mathrm{KM}(1,2)$, but not by $\mathrm{DQB} 1{ }^{\star} 0501$ or $\mathrm{KM}(1,2)$ alone. It was noted that individuals having $\operatorname{KM}(1,2)$ but not having DQB ${ }^{\star} 0501$ were significantly less frequently found in ACA positive SSc compared with ACA negative SSc patients $(\mathrm{p}=0.04)$. Similar analyses in combinations of the presence or absence of the SSc related ANA associated MHC class II alleles (DRB1* 1502 in anti-topo I, DQB $1^{\star} 0302$ in anti-U1snRNP, and $\mathrm{DQB} 1{ }^{\star} 0501$ in $\mathrm{ACA}$ ) and $\mathrm{GM} / \mathrm{KM}$ allotypes failed to observe an additional interactive effect on the ANA response (data not shown).

\section{Discussion}

This is the first report analysing Ig allotype gene polymorphisms in SSc patients. Our results confirm the results of previous studies using serological typing methods, which described that GM/KM phenotypes were not associated with SSc in itself. ${ }^{1326-28}$ Instead, our results showed that the production of ACA, one of major SSc related autoantibodies, was influenced by Ig allotype gene polymorphisms, based on the following findings: (a) G1M(f) and $\mathrm{G} 2 \mathrm{M}(\mathrm{n}+)$ were negatively associated with the presence of ACA in SSc patients; and (b) DQB $1^{\star} 0501$ and $\mathrm{KM}(1,2)$ synergically promoted the production of ACA. Taken together, this study strongly suggests that Ig allotypes are not related to disease expression in SSc patients, but are associated with the induction of certain SSc related ANA response.

Previously reported associations between ANA specificities and Ig allotypes included the associations of anti-La/SS-B antibody and anti-double stranded-DNA antibody responses with serologically determined $\mathrm{KM}(1)$, which corresponds to $\mathrm{KM}(1)$ and $\mathrm{KM}(1,2)$ together by our typing methods. ${ }^{12} 13$ One of the authors (JPP) previously showed the lack of associations between serologically determined GM/KM phenotypes and ACA. ${ }^{26}$ The reasons for this discordant result are unclear; possible explanations include patient selection methods and ethnic backgrounds of SSc patients studied. ACA positive patients in this study were selected based on the ACR classification criteria of SSc, whereas ACA positive patients in the previous study contained patients with milder disease manifestations who did not satisfy the ACR criteria but had some components of calcinosis, Raynaud's phenomenon, oesophageal dysmotility, sclerodactyly, and telangiectasia (CREST syndrome). Racial difference could be another explanation for this inconsistent result, as SSc patients in this study were all Japanese living in a small geographical area while North American white patients were examined in the previous study. It has been shown that distribution of SSc related ANAs and MHC class II alleles associated with SSc related ANAs were distinctly different among racial groups. ${ }^{329}$ In addition, allelic distribution of $\mathrm{GM} / \mathrm{KM}$ allotypes are also shown to be vari- able among people with various ethnic origins. ${ }^{24} 30$

Our results suggest that the coincidence of two independent genetic markers, $\mathrm{DQB} 1{ }^{\star} 0501$ and $\operatorname{KM}(1,2)$, increases the risk of an ACA autoimmune response. The combined effects of HLA and GM/KM phenotypes have been observed in the antibody response to a bacterial antigen ${ }^{14}$ and in the development of several autoimmune diseases. ${ }^{31}{ }^{32}$ Genth et al reported that the coexistence of DR4 and $\operatorname{Gm}(1,3 ; 5,21)$ was related to anti-U1snRNP antibody production in 35 patients with connective tissue disease (only six patients were diagnosed as having SSc). ${ }^{15}$ In the present study, interactive effects between $\mathrm{DQB} 1^{\star} 0302$ and GM/KM allotypes were not found in the production of anti-U1snRNP antibody. Furthermore, we also failed to observe interactive effects on anti-U1snRNP antibody formation with other MHC class II markers, including all combined DR4 specificity (DRB ${ }^{\star} 0401$ $\left.{ }^{\star} 0413\right)$ and each DR4 associated DRB1 allele (data not shown). This paradoxical finding could be because of racial differences between a white population and Japanese, because we found that DR4, which was shown to be associated with anti-U1snRNP antibody in the Genth report, was not associated with antiU1snRNP antibody in Japanese. ${ }^{6}$

Possible mechanisms by which polymorphisms located in the constant regions of Igs influence ANA responses include linkage disequilibrium between certain Ig allotypic genes and pathogenic genes or variable regions of Igs, and influence on conformation (affinity) of the antigen binding site of autoantibodies. Interactive effects of MHC class II and KM genes on ACA production suggest another possibility that Ig allotypes affect uptake of autoantigens via surface Ig, and processing and presentation of autoantigens by B cells. Recently, one of us (MK) and others demonstrated the requirement of MHC class II restricted $\mathrm{T}$ and $\mathrm{B}$ cell collaboration for autoantibody production in SSc patients ${ }^{33}$ and in lupus prone mice. ${ }^{34}$ It has been proposed that autoantibody production is a result of the generation of cross reactive $B$ cells, initially primed by foreign protein serving as a molecular mimic, that then bind, process, and present self protein. ${ }^{35}$ The cross reactive $\mathrm{B}$ cells can subsequently prime autoreactive $\mathrm{T}$ cells, as B cells have ability to concentrate specific antigen via surface Ig and present small quantities of determinants to $\mathrm{T}$ cells in the context of MHC class II molecules. Therefore, it is possible that differences in constant region of surface Ig affect the antigen processing/presenting pathway and induce the expression of self determinants that fit in the peptide binding groove of susceptible MHC class II molecules.

In summary, Ig allotype gene polymorphisms were not associated with susceptibility to SSc, but our results strongly suggest that MHC class II and KM genes, two independent immune response genes, interactively promote the production of ACA. 
We thank Dr Carwile LeRoy for critical reading of this manuscript. This work was supported by the Scleroderma Grant for Intractable Disease from the Japanese Ministry of Health and Welfare and the US Department of Energy grant (DE-FC02-98CH10902).

1 Medsger T A Jr. Systemic sclerosis (scleroderma), localized forms of scleroderma, and calcinosis. In: D J McCarty, W J Koopman, eds. Arthritis and allied conditions. Philadelphia Lea and Febiger, 1993:1253-92.

2 Silman A J, Newman J. Genetic and environmental factors in scleroderma. Curr Opin Rheumatol 1994;6:607-11.

3 Reveille J D. Molecular genetics of systemic sclerosis. Curr Opin Rheumatol 1995;7:522-8.

4 Kuwana M, Kaburaki J, Okano Y, Inoko H, Tsuji K. The HLA-DR and DQ genes control the autoimmune response to DNA topoisomerase I in systemic sclerosis (scleroderma). J Clin Invest 1993;92:1296-301.

5 Kuwana M, Okano Y, Kaburaki J, Inoko H. HLA class II genes associated with anticentromere antibody in Japanese patients with systemic sclerosis (scleroderma). Ann Rheum Dis 1995;54:983-7.

6 Kuwana M, Okano Y, Kaburaki J, Tsuji K, Inoko H. Major histocompatibility complex class II gene associations with histocompatibility complex class II gene associations with anti-U1 small nuclear ribonucleoprotein antibody: relationship to immunoreactivity with individua

7 Grubb R. Advances in human immunoglobulin allotypes. Exp Clin Immunogenet 1995;12:191-7.

8 Schur P H, Pandey J P, Fedrick J A. Gm allotypes in white patients with systemic lupus erythematosus. Arthritis Rheum 1985;28:828-30.

9 Nakao Y, Matsumoto H, Miyazaki T, Nishitani H, Ota K, Fujita $\mathrm{T}$, et al. $\mathrm{Gm}$ allotypes in myasthenia gravis. Lancet 1980;i:677-80

10 Uno H, Sasazuki T, Tamai H, Matsumoto H. Two major genes, linked to HLA and Gm, control susceptibility to Graves' disease. Nature 1981;292:768-70.

11 Dugoujon J M, Cambon-Thomsen A. Immunoglobulin allotypes $(\mathrm{Gm}$ and $\mathrm{Km})$ and their interactions with HLA antigens in autoimmune diseases: a review. Autoimmunity 1995;22:245-60.

12 Whittingham S, Propert D N, Mackay I R. A strong association between the antinuclear antibody anti-La (SS-B) and tion between the antinuclear antibody anti-La (SS-B) and
the kappa chain allotype $\mathrm{Km}(1)$. Immunogenetics 1984 ; the kappa

13 Hoffman R W, Sharp G C, Irvin W S, Anderson S K Hewett J E, Pandey J P. Association of Immunoglobulin $\mathrm{Km}$ and $\mathrm{Gm}$ allotypes with specific antinuclear antibodies and disease susceptibility among connective tissue disease patients. Arthritis Rheum 1991;34:453-8.

14 Whittingham S, Mathews J D, Schanfield M S, Matthews J $\mathrm{V}$, Tait B D, Morris P J, et al. Interactive effect of Gm allotypes and HLA-B locus antigens on the human antibody response to a bacterial antigen.Clin Exp Immunol 1980;40:8-15.

15 Genth E, Zarnowski H, Mierau R, Wohltmann D, Hartl P W. HLA-DR4 and $\mathrm{Gm}(1,3 ; 5,21)$ are associated with U1-nRNP antibody positive connective tissue disease. Ann Rheum Dis 1987;46:189-96.

16 Balbin M, Grubb A, Abrahamson M, Grubb R. Determination of allotypes G1m (f) and G1m (z) at the genomic level
by subclass-specific amplification of DNA and use of by subclass-specific amplification of DNA and use of 95.

17 Brusco A, de Lange G G, Boccazzi C, Carbonara A O. Molecular characterization of G2m (n+) and G2m (n-) allotypes. Immunogenetics 1995;42:414-17.
18 Balbin M, Grubb A, de Lange G G, Grubb R. DNA sequences specific for Caucasian $\mathrm{G} 3 \mathrm{~m}$ (b) and (g) allotypes: allotyping at the genomic level. Immunogenetics 1994;39:187-93.

19 Moxley G, Gibbs R S. Polymerase chain reaction-based genotyping for allotypic markers of immunoglobulin kappa shows allelic association of $\mathrm{Km}$ with kappa variable segment. Genomics 1992;13:104-8.

20 Subcommittee for Scleroderma Criteria of the American Rheumatism Association Diagnostic and Therapeutic classification of systemic sclerosis (scleroderma). Arthritis Rheum 1980;23:581-90.

21 Kuwana M, Kaburaki J, Okano Y, Tojo T, Homma M. Clinical and prognostic associations based on serum antinuclear antibodies in Japanese patients with systemic sclerosis. Arthritis Rheum 1994;37:75-83.

22 Inoko H, Ota M. PCR-RFLP. In: K M Hui, J Bidwell, eds. Handbook of HLA typing techniques. Boca Raton: CRC Press, 1993: 9-70.

23 Bishop Y M M, Fienberg S E, Hollad P W. Discrete multivariate analysis - theory and practice. Cambridge: MIT Press, 1975.

24 Steinberg A G, Cook C E. The distribution of human immunoglobulin allotypes. New York: Oxford University Press, 1981.

25 Matsumoto $\mathrm{H}$. Characteristics of Mongoloid and neighboring populations based on the genetic markers of human immunoglobulins. Hum Genet 1988;80:207-18.

26 Chen Z, Fedrick J A, Pandey J P, Silver R M, Maricq H R, Fudenberg $\mathrm{H} \mathrm{H}$, et al. Anticentromere antibody and immunoglobulin allotypes in scleroderma. Arch Dermatol 1985;121:339-44.

27 McGregor A R, Watson A, Yunis E, Pandey J P, Takehara K, Tidwell J T, et al. Familial clustering of scleroderma spectrum disease. Am J Med 1988;84:1023-32.

28 Pereira S, Black C, Welsh K, Ansell B, Jayson M, Maddison $\mathrm{P}$, et al. Autoantibodies and immunogenetic in 30 patients with systemic sclerosis and their families. J Rheumatol $1987 ; 14: 760-5$.

29 Kuwana M, Okano Y, Kaburaki J, Tojo T, Medsger T A Jr. Racial differences in the distribution of systemic sclerosisrelated serum antinuclear antibodies. Arthritis Rheum 1994;37:902-6.

30 Cavalli-Sforza L L, Menozzi P, Piazza A. The history and geography of human genes. Princeton: Princeton University Press, 1994

31 Whittingham S, Mathews J D, Schanfield M S, Tait B D, Mackay I R. Interaction of HLA and Gm in autoimmune chronic active hepatitis. Clin Exp Immunol 1981;43:80-6. 32 Whittingham S, Mathews J D, Schanfield M S, Tait B D, Mackay I R. HLA and Gm genes in systemic lupus erythematosus. Tissue Antigens 1983;21:50-7.

33 Kuwana M, Medsger T A Jr, Wright T M. T and B cell collaboration is essential for the autoantibody response to DNA topoisomerase I in systemic sclerosis. J Immunol 1995;155:2703-14.

34 Sobel E S, Kakkanaiah V N, Kakkanaiah M, Cheek R L, Cohen P L, Eisenberg R A. T - B collaboration for autoantibody production in $\mathrm{lpr}$ mice is cognate and MHCrestricted. J Immunol 1994;152:6011-16.

35 Mamula M J, Fatenejad S, Craft J. B cells process and present lupus autoantigens that initiate autoimmune $\mathrm{T}$ cell responses. J Immunol 1994;152:1453-61. 